\title{
Potensi Antidepresan Beberapa Tumbuhan Suku Fabaceae
}

\author{
Nur Ariska Melanti", Ratu Choesrnia \\ Prodi Farmasi, Fakultas Matematika dan Ilmu Pengetahuan Alam, Universitas \\ Islam Bandung, Indonesia. \\ *Ariskam@yahoo.com, choesrina1@gmail.com
}

\begin{abstract}
One of the therapies used to cope with depression is by using antidepressant. Fabaceae tribe (legum) has been widely used to overcome various diseases and is one of the potential plant tribes which has antidepressant activity. This research aims to determine the antidepressant activity of various plants of Fabaceae tribes along with the contents and to determine the dose that has an antidepressant effect from certain Fabaceae tribe plants. This research is conducted by literature study. The journal search is conducted by using "Antidepressants activity of plant", "Fabaceae as antidepressants", "Antidepressant like activity of Fabaceae" and "Pemanfaatan suku Fabaceae" as keywords. The process of data search used as the reference of literature study is conducted through database such as Google Scholar, ScienceDirect, Taylor \& Francis, MDPI, BJPS and ResearchGate. The literature criteria used are scientific articles, research journals and books containing compounds, activities and plants used as antidepressant. The stages conducted in this research are literature search and selection, literature review, formation, discussion and conclusion. Based on the library research that have been conducted, it can be concluded that Albizzia julibrissin, Cassia singueana, Ceratonia siliqua L., Erythrina variegata, Trigonella foenum-graecum, Lotus corniculatus L., Ormosia henryi prain and Prosopis cineraria have antidepressant activities. The majority of antidepressant action mechanism of the Fabaceae tribe plants is through the inhibition of Monoamine Oxidase (MAO) enzyme.
\end{abstract}

\section{Keywords: Antidepressant, Fabaceae, literature study.}

Abstrak. Salah satu terapi yang digunakan untuk mengatasi depresi adalah dengan penggunaan antidepresan. Suku Fabaceae (legum) telah banyak digunakan untuk mengatasi berbagai macam penyakit dan merupakan salah satu suku tumbuhan potensial yang memiliki aktivitas sebagai antidepresan. Penelitian ini bertujuan untuk mengetahui aktivitas antidepresan dari beberapa tumbuhan suku Fabaceae beserta kandungannya dan mengetahui dosis yang berefek antidepresan dari beberapa tumbuhan suku Fabaceae. Penelitian dilakukan dengan studi literatur. Penelusuran jurnal dilakukan menggunakan kata kunci "Antidepressants activity of plant", "Fabaceae as antidepressants", "Antidepressant like activity of Fabaceae" dan "Pemanfaatan suku Fabaceae". Proses pencarian data yang digunakan sebagai acuan studi literatur dilakukan melalui database seperti Google Scholar, ScienceDirect, Taylor \& Francis, MDPI, BJPS dan ResearchGate. Kriteria literatur yang digunakan adalah artikel ilmiah, jurnal penelitian dan buku yang berisi tentang kandungan senyawa, aktivitas dan tumbuhan yang berfungsi sebagai antidepresan. Tahapan yang dilakukan pada penelitian ini yaitu pencarian dan pemilihan literatur, review literatur, penyusunan, pembahasan dan kesimpulan. Berdasarkan penelusuran pustaka yang telah dilakukan, dapat disimpulkan bahwa Albizzia julibrissin, Cassia singueana, Ceratonia siliqua L., Erythrina variegata, Trigonella foenum-graecum, Lotus corniculatus L., Ormosia henryi prain dan Prosopis cineraria memiliki aktivitas antidepresan. Mayoritas mekanisme kerja antidepresan dari tumbuhan-tumbuhan suku Fabaceae adalah melalui penghambatan enzim Monoamine Oxidase (MAO).

Kata Kunci: Antidepresan, Fabaceae, studi literatur. 


\section{A. Pendahuluan}

Depresi merupakan masalah kesehatan jiwa yang utama saat ini (Hawari D, 2011). Berdasarkan data dari Institute for Health Metrics and Evaluation (IHME) yang menyebutkan bahwa beberapa jenis gangguan jiwa yang diprediksi dialami oleh penduduk di Indonesia diantaranya adalah depresi, dimana dalam masa tiga dekade (1990-2017) terjadi perubahan pola penyakit mental dan gangguan depresi tetap menduduki urutan pertama (INFODATIN, 2019). Salah satu terapi yang digunakan untuk mengatasi depresi adalah dengan penggunaan antidepresan.

Di Indonesia, masyarakat sering menggunakan tumbuhan obat untuk pengobatan penyakit. Sehingga diperlukan data ilmiah yang akurat untuk mendukung penggunaan tumbuhan herbal dalam pengobatan sehingga efek farmakologinya lebih maksimal dan efek samping yang membahayakan dapat dihindari. Salah satu tumbuhan Indonesia yang dimanfaatkan sebagai obat herbal adalah tumbuhan dari suku Fabaceae. Suku Fabaceae (legum) telah banyak digunakan untuk mengatasi berbagai macam penyakit dan merupakan salah satu suku tumbuhan potensial yang memiliki aktivitas sebagai antidepresan. Fabaceae adalah suku polong-polongan yang mempunyai distribusi yang luas di kawasan tropis salah satunya Indonesia dan terdiri dari 18.000 spesies (Langran et al., 2010). Dengan mempertimbangkan jumlah spesies yang besar, perhatian khusus telah diberikan pada senyawa antidepresan yang terkandung dalam tumbuhan dari kelompok ini, yang saat ini sedang diteliti pada berbagai model hewan (Chwil M et al, 2017). Oleh karena itu maka akan dilakukan penelitian dengan metode studi literatur tentang potensi antidepresan beberapa tumbuhan suku Fabaceae.

Berdasarkan pemaparan diatas, dapat dirumuskan bagaimana aktivitas antidepresan dari beberapa tumbuhan suku Fabaceae beserta kandungannya dan berapakah dosis yang berefek antidepresan. Penelitian ini bertujuan untuk mengetahui aktivitas antidepresan dari beberapa tumbuhan suku Fabaceae beserta kandungannya dan mengetahui dosis yang berefek antidepresan dari beberapa tumbuhan suku Fabaceae. Manfaat dari penelitian ini yaitu diharapkan memberikan informasi ilmiah mengenai khasiat dari suku Fabaceae sebagai antidepresan dan dapat memberikan dukungan bagi pengembangan keilmuan di bidang kefarmasian serta dapat meningkatkan pemanfaatan tumbuhan obat Indonesia.

\section{B. Metode Penelitian}

Penelitian dilakukan dengan studi literatur. Proses pencarian data yang digunakan sebagai acuan studi literatur dilakukan melalui database seperti Google Scholar, Sciencedirect, Taylor \& Francis, MDPI, BJPS dan Researchgate. Kriteria literatur yang digunakan adalah artikel ilmiah, jurnal penelitian dan buku yang berisi tentang kandungan senyawa, aktivitas dan tumbuhan yang berfungsi sebagai antidepresan.

\section{Hasil dan Pembahasan}

\section{Tumbuhan Suku Fabaceae yang Berpotensi sebagai Antidepresan}

Berdasarkan hasil penelusuran pustaka beberapa tumbuhan suku Fabaceae yang memiliki aktivitas antidepresan adalah Albizzia julibrissin, Cassia singueana, Ceratonia siliqua L., Erythrina variegata, Trigonella foenum-graecum, Lotus corniculatus L., Ormosia henryi prain dan Prosopis cineraria.Tumbuhan-tumbuhan tersebut disebutkan memiliki aktivitas sebagai antidepresan yang dapat dilihat pada tabel 1 . 
Tabel 1. Beberapa tumbuhan suku Fabaceae yang memiliki aktivitas antidepresan

\begin{tabular}{|c|c|c|c|c|c|c|c|}
\hline No & Nama Tumbuhan & $\begin{array}{l}\text { Bagian yang } \\
\text { Digunakan }\end{array}$ & Bentuk & Hewan Uji & $\begin{array}{l}\text { Metode } \\
\text { Pengujian }\end{array}$ & $\begin{array}{c}\text { Dosis yang Berefeek } \\
\text { Antideppesan }\end{array}$ & Referensi \\
\hline 1 & Albizzia julibrissin & Kulit batang & Fraksí & Mencit & TST & $200 \mathrm{mg} / \mathrm{kg} \mathrm{BB}$ & (Kim et a., 2007) \\
\hline 2 & Cassia singueanna & Daun & Ekstrak & Tikus & FST dan TST & $100 \mathrm{mg} / \mathrm{kg} \mathrm{BB}$ & (borahim A. Y, et al, 2019) \\
\hline 3 & Ceratonia siligua L. & Buah & Ekstrak & Mencit & FST dan TST & $25 \mathrm{mg} / \mathrm{kg} \mathrm{BB}$ & (Agrawal et al., 2011) \\
\hline 4 & Entyrinina varregata & Kullit kayu & Ekstrak & Mencit & FST & $200 \mathrm{mg} / \mathrm{kg} B \mathrm{BB}$ & (Martins dan Brijesh, 2019) \\
\hline 5 & Trigonell foomum-grcecum & Biji & Fraksi & Mencit & FST, IST, dan SPT & $140 \mathrm{mg} / \mathrm{kgBB}$ & (Wang J et al., 2019) \\
\hline 6 & Lotus corniculatulus L. & Aerial parts & $\begin{array}{l}\text { Ekstrak dan } \\
\text { Fraksi }\end{array}$ & Mencit & FST dan TST & $100 \mathrm{mg} / \mathrm{kg} B \mathrm{BB}$ & (Deetli et al., 2020) \\
\hline 1 & Ormosia hemryi prain & Daun & Fraksi & Mencit & SPT, LT, dan IST & $150 \mathrm{mg} / \mathrm{kg} B \mathrm{BB}$ & (Luet al., 2019) \\
\hline 8 & Prosopis cinererria & Daun & Ekstrak & Mencit & FST & $200 \mathrm{mg} / \mathrm{kg} \mathrm{BB}$ & (George et al., 2012) \\
\hline
\end{tabular}

Dari tabel 1 dapat diketahui tumbuhan obat suku Fabaceae yang berpotensi sebagai antidepresan dan dosis yang berefek sebagai antidepresan. Tumbuhan-tumbuhan tersebut diketahui memiliki aktivitas antidepresan yang diuji dengan berbagai model pengujian antidepresan dan menunjukkan hasil yang positif.

\section{Kandungan Senyawa Tumbuhan Suku Fabaceae}

Tumbuhan suku Fabaceae yang memiliki aktivitas antidepresan mengandung senyawa metabolit beragam yang ditemukan pada bagian daun, kulit batang, biji, buah dan aerial parts. Beberapa penelitian telah dilakukan untuk mengetahui kandungan senyawa yang terdapat pada beberapa tumbuhan suku ini. Beberapa senyawa tersebut ditunjukan pada tabel 2 . 
Tabel 2. Kandungan senyawa tumbuhan suku Fabaceae yang memiliki aktivitas antidepresan

\begin{tabular}{|c|c|c|c|c|}
\hline No & Nama Tumbuhan & Bagian Tumbuhan & Kandungan Senyawa & Referensi \\
\hline 1 & Albizzia julibrissin & Kulit batang & $\begin{array}{l}\text { Turunan flavon, asam tak jenuh, lignan } \\
\text { glikosida dan saponin triterpenoidal }\end{array}$ & $\begin{array}{l}\text { Kinjo et al., 1992; Jung et } \\
\text { al., 2003, 2004) }\end{array}$ \\
\hline 2 & Cassia singueana & Daun & $\begin{array}{l}\text { Tanin, karbohidrat, saponin, flavonoid, } \\
\text { steroid, alkaloid, dan gula pereduksi }\end{array}$ & (Alkali Y.I, et al., 2018) \\
\hline 3 & Ceratonia siliqua $\mathrm{L}$. & Buah & $\begin{array}{l}\text { Polifenol (proanthocyanidins, ellagitannins, dan } \\
\text { gallotannins) }\end{array}$ & (Avallone et al., 1997) \\
\hline 4 & Erythrina variegata & Kulit kayu & $\begin{array}{l}\text { 2-amino-3-metil-1-butanol, feniletilamin, eriodiktil, } \\
\text { daidzein, pomiferin, n-etil arakidonoil amina, inosin } \\
\text { difosfat, trimipramine, granisetron, asam 3,4- } \\
\text { dihidroksimandelat dan dodekana }\end{array}$ & (Martins dan Brijesh, 2019) \\
\hline 5 & Trigonella foenum-graecum & Biji & $\begin{array}{l}\text { Flavonoid (Kaempferol 3-(p-coumaryl) glukosida, } \\
\text { Quercetin 4-O- } \beta \text {-d-glucopyranoside, Apigenin 4',7-O- } \\
\text { diglucoside, Schaftoside, Isoschaftoside dan Apigenin } \\
\text { 8-C- } \alpha \text {-D-glucopyranoside) }\end{array}$ & (Wang J et al., 2019) \\
\hline 6 & Lotus corniculatus $\mathrm{L}$. & Aerial parts & $\begin{array}{l}\text { Flavonoid dan glikosida (quercetin, naringenin, } \\
\text { hyperoside, quercetin-O-deoxyhexoside-O-hexoside, } \\
\text { quercetin-3-O-rhamnoside-7-O-glucoside,quercetin-3, } \\
\text { 7dirhamnoside,isoquercitrin, quercetin-O-pentoside, } \\
\text { quercitrin, kaempferol-3-O-[xylosyl-(1 } \rightarrow 2 \text { )- } \\
\text { galactoside]-7-O-rhamnoside, kaempferol-7-O- } \\
\text { glucoside, afzelin, kaempferol-O- } \\
\text { deoxyhexosylhexoside- O-deoxyhexoside, kaempferol- } \\
\text { 3-O-rhamnoside-7-O-glucoside, gossypetin, } \\
\text { gossypetin-3-O-galactoside, gossytrin, medicarpin, } \\
\text { medicarpin-3-O- } \beta \text {-d-glucopyranosid) dan saponin } \\
\text { (soyasaponin I, dehydrosoyasaponin I, pharbitoside } \\
\text { A; benzoic acid and cinnamic acid derivatives include } \\
\text { p-coumaric acid, caffeic acid and chlorogenic acid) }\end{array}$ & $\begin{array}{l}\text { (Mezrag et al., 2014; } \\
\text { Reynaud et al., 1982; } \\
\text { Walewska et al., 1984) }\end{array}$ \\
\hline 7 & Ormosia henryi prain & Daun & $\begin{array}{l}\text { Flavonoid (flavon, flavon C-glikosida, flavon O- } \\
\text { glikosida, isoflavon, isoflavon O-glikosida, } \\
\text { prenylflavon dan polimetoksiflavon) }\end{array}$ & (Lu et al., 2019) \\
\hline 8 & Prosopis cineraria & Daun & $\begin{array}{l}\text { Saponin, flavonoid, alkaloid, glikosida, tanin, dan } \\
\text { senyawa fenolik }\end{array}$ & (George et al., 2012) \\
\hline
\end{tabular}

\section{Senyawa yang Berperan dan Mekanisme Kerjanya sebagai Antidepresan}

Tabel 3. Senyawa yang berperan dan mekanisme kerjanya sebagai antidepresan 


\begin{tabular}{|c|c|c|c|c|}
\hline No & Nama Tumbuhan & Senyawa yang Berperan & Mekanisme Kerja & Referensi \\
\hline 1 & Albizzia julibrissin & Belum diketahui & Memodulasi reseptor $5-\mathrm{HT}_{1 \mathrm{~A}}$ & (Kim et al., 2007) \\
\hline 2 & Cassia singueana & Belum diketahui & $\begin{array}{l}\text { Menghambat reuptake monoamin nerotransmitter } \\
\text { (norepinefrin, epinefrin, dopamin dan serotonin) atau } \\
\text { menghambat metabolisme monoamin }\end{array}$ & (Ibrahim A.Y, et al., 2019) \\
\hline 3 & Ceratonia siliqua $\mathrm{L}$. & Belum diketahui & Mengatur sistem dopaminergik dan adrenergik & (Agrawal et al., 2011) \\
\hline 4 & Erythrina variegata & Belum diketahui & Menghambat MAO-A dan MAO-B & (Martins dan Brijesh, 2019) \\
\hline 5 & Trigonella foenum-graecum & $\begin{array}{l}\text { Kaempferol 3-(p-coumaryl) } \\
\text { glukosida, Quercetin 4-O- } \beta \text {-d- } \\
\text { glucopyranoside, Apigenin 4',7-O- } \\
\text { diglucoside, Schaftoside, } \\
\text { Isoschaftoside dan Apigenin 8-C- } \alpha \text { - } \\
\text { D-glucopyranoside }\end{array}$ & $\begin{array}{l}\text { Menghambat ekspresi dan aktivitas MAO-A } \\
\text { (Menurunkan regulasi jalur KLF11/SIRT1-MAO-A) }\end{array}$ & (Wang J et al., 2019) \\
\hline 6 & Lotus corniculatus $\mathrm{L}$. & $\begin{array}{l}\text { Medicarpin-3-O-glucoside, } \\
\text { gossypetin-3-O-glucoside } \\
\text { dan naringenin-7-O-glucoside }\end{array}$ & Menghambat MAO-A dan MAO-B & (Dereli et al., 2020) \\
\hline 7 & Ormosia henryi prain & $\begin{array}{l}\text { Flavon C-glikosida (luteolin 6-C- } \\
\text { glucoside (isoorientin), luteolin 8-C- } \\
\text { glucoside (orientin) dan apigenin 6- } \\
\text { C-glucoside (isovitexin)) }\end{array}$ & Belum diketahui & (Lu et al., 2019) \\
\hline 8 & Prosopis cineraria & Belum diketahui & Belum diketahui & \\
\hline
\end{tabular}

Dari tabel 3 dapat diketahui bahwa terdapat tiga (3) tumbuhan obat suku Fabaceae yang telah diketahui senyawa aktif yang berperan terhadap aktivitas antidepresan yaitu Trigonella foenum-graecum, Lotus corniculatus L. dan Ormosia henryi prain. Oleh karena itu, ketiga tumbuhan ini merupakan tumbuhan yang paling berpotensi sebagai antidepresan. Berdasarkan tabel diatas maka dapat diketahui bahwa tumbuhan suku Fabaceae memiliki potensi sebagai antidepresan dengan berbagai mekanisme kerja. Mayoritas mekanisme kerja antidepresan dari tumbuhan-tumbuhan suku Fabaceae adalah melalui penghambatan enzim Monoamine Oxidase (MAO). Mekanisme kerja lainnya yaitu modulasi reseptor 5-HT $1 \mathrm{~A}$, menghambat reuptake monoamine, mengatur sistem adrenergik dan dopaminergik. Tumbuhan obat suku Fabaceae yang memiliki referensi lengkap hingga mekanisme kerja antidepresan adalah Trigonella foenum-graecum dan Lotus corniculatus L. Tumbuhan Ormosia henryi prain masih memerlukan penelitian mengenai mekanisme aksi senyawa aktif. Tumbuhan Albizzia julibrissin, Cassia singueana, Ceratonia siliqua L. dan Erythrina variegata masih memerlukan penelitian mendalam terkait senyawa aktif yang berperan sebagai antidepresan. Sedangkan, tumbuhan Prosopis cineraria masih memerlukan penelitian terkait senyawa aktif dan mekanisme kerja antidepresan.

\section{Potensi Albizzia julibrissin sebagai Antidepresan}

Albizzia julibrissin memiliki nama umum mimosa atau pohon sutra merupakan tumbuhan yang tersebar luas di Asia. Fraksi metilen klorida Albizzia julibrissin $(200 \mathrm{mg} / \mathrm{kgBB})$ secara signifikan mengurangi waktu imobilitas pada pengujian tail suspension test (TST) dibandingkan dengan kelompok kontrol sehingga dengan demikian menunjukkan efek seperti antidepresan dimana efek ini sebanding dengan imipramine $(10 \mathrm{mg} / \mathrm{kg})$. Fraksi metilen klorida Albizzia julibrissin memberikan efek antidepresan melalui modulasi reseptor $5-\mathrm{HT}_{1 \mathrm{~A}}$, hal ini dibuktikan dengan studi manipulasi farmakologis dimana fraksi metilen klorida Albizzia julibrissin mengurangi waktu imobilitas mencit yang diinduksi WAY-100635 (antagonis 5$\mathrm{HT}_{1 \mathrm{~A}}$ ) dan pindolol (antagonis $5-\mathrm{HT}_{1 \mathrm{~A}} \mathrm{l}_{1 \mathrm{~B}}$ ), tetapi tidak memberikan efek antidepresan pada tikus yang diinduksi GR5556 (antagonis 5-HT $1 \mathrm{~B}$ ) dan ketanserin (antagonis reseptor 5- $\mathrm{HT}_{2 \mathrm{~A}}$ ) (Kim et al., 2007).

\section{Potensi Cassia singueana sebagai Antidepresan}

Cassia singueana dikenal secara lokal sebagai pambisuma (Margi) dan rumfu (Hausa) di utara Nigeria (Adzu et al., 2003). Ekstrak metanol daun Cassia singueana $(100 \mathrm{mg} / \mathrm{kgBB})$ secara signifikan mengurangi durasi imobilitas tikus pada pengujian forced swim test (FST) dan tail suspension test (TST) yang menunjukkan adanya aktivitas antidepresan. Efek antidepresan yang diberikan oleh ekstrak metanol daun Cassia singueana kemungkinan melalui 
peningkatkan konsentrasi monoamin seperti norepinefrin, epinefrin, dopamin dan serotonin diekstraseluler dengan menghambat mekanisme pengambilan atau menghambat metabolisme mereka (Ibrahim A.Y, et al., 2019).

\section{Potensi Ceratonia siliqua L. Sebagai Antidepresan}

Ceratonia siliqua L. memiliki nama umum pohon carob. Ekstrak aseton buah ceratonia siliqua L. memiliki aktivitas sebagai antidepresan yang signifikan dengan menurunkan waktu imobilitas pada tail suspension test (TST) dan forced swim test (FST) dengan dosis yang memberikan efek antidepresan adalah $25 \mathrm{mg} / \mathrm{kg}$ BB. Efek antidepresan ekstrak aseton buah Ceratonia siliqua L. dimediasi oleh dopamin dan noradrenalin, hal ini dibuktikan dengan penurunan waktu imobilitas mencit yang diinduksi dengan prazosin (antagonis $\alpha_{1^{-}}$ adrenoseptor) dan etikloprid (antagonis $\mathrm{D}_{2}$-reseptor dopamin klasik) tetapi tidak memberikan efek antidepresan pada mencit yang diinduksi p-klorofenilalanin (penghambat sintesis serotonin) dan baklofen (agonis $\mathrm{GABA}_{\mathrm{B}}$ ). Hal ini menunjukkan bahwa ekstrak aseton buah Ceratonia siliqua L. mungkin menghasilkan efek antidepresan dengan reseptor $\alpha_{1^{-}}$ adrenoseptor dan dopamin $\mathrm{D}_{2}$ dan tidak dimediasi oleh sistem serotonergik atau sistem GABAergik (Agrawal et al., 2011).

\section{Potensi Erythrina variegata sebagai Antidepresan}

Erythrina variegata yang lebih dikenal dengan nama dadap ayam. Pada penelitian Martins dan Brijesh (2019) ekstrak etanol kulit kayu Erythrina variegata terbukti memberikan aktivitas antidepresan pada dosis $200 \mathrm{mg} / \mathrm{kg}$ BB. Ekstrak ekstrak etanol kulit kayu Erythrina variegata menunjukkan penurunan yang signifikan dalam periode waktu imobilitas pada model forced swim test (FST) akut dan kronis. Kemudian, ketika dilakukan prosedur chronic unpredictable mild stress (CUMS) untuk menilai potensi penerapan ekstrak etanol kulit kayu Erythrina variegata sebagai tambahan untuk obat SSRI dan pengaruhnya terhadap aktivitas MAO-A dan B didapatkan hasil bahwa ekstrak etanol kulit kayu Erythrina variegata $(200 \mathrm{mg} / \mathrm{kg})$ yang dikombinasi dengan escitalopram $(15 \mathrm{mg} / \mathrm{kg})$ menunjukkan penghambatan aktivitas MAO-A dan B secara signifikan lebih besar jika dibandingkan dengan escitalopram saja.

\section{Potensi Trigonella foenum-graecum sebagai Antidepresan}

Trigonella foenum-graecum yang lebih dikenal dengan nama fenugreek merupakan tumbuhan yang biasa ditemukan di wilayah Mediterania dan Asia Barat. Pada penelitian Wang $\mathbf{J}$ et al (2019) fraksi etanol biji Trigonella foenum-graecum (140 mg/kg BB) menghasilkan efek seperti antidepresan pada mencit yang diinduksi chronic restraint stress (CRS) menggunakan metode forced swim test (FST), tail suspension test (TST) dan sucrose preference test (SPT). pemberian fraksi etanol biji Trigonella foenum-graecum secara nyata memulihkan CRS yang menginduksi perubahan konsentrasi kortikosteron serum, neurotransmiter korteks prefrontal (NE, 5-HT dan DA), neurotransmiter hipocampus (NE, 5-HT dan DA), neurotransmiter striatum (NE) dan menunjukkan penghambatan signifikan aktivitas MAO-A di korteks prefrontal dan hippocampus. Wang J et al (2019) juga melakukan pengujian untuk menentukkan tingkat ekspresi protein KLF11, SIRT1, MAO-A dengan analisis western blot. Hasilnya, fraksi etanol biji Trigonella foenum-graecum secara signifikan menurunkan tingkat ekspresi protein KLF11, SIRT1 dan MAO-A di korteks prefrontal dan hippocampus. ini menunjukkan bahwa fraksi etanol biji Trigonella foenum-graecum $(140 \mathrm{mg} / \mathrm{kg} \mathrm{BB})$ dapat menunjukkan efek seperti antidepresan dengan menurunkan regulasi jalur KLF11/SIRT1MAO-A, menghambat ekspresi dan aktivitas MAO-A dan meningkatkan level neurotransmiter monoamina. Fraksi etanol biji Trigonella foenum-graecum diketahui memiliki senyawa aktif Kaempferol 3-(p-coumaryl) glukosida, Quercetin 4-O- $\beta$-d-glucopyranoside, Apigenin 4',7-Odiglucoside, Schaftoside, Isoschaftoside dan Apigenin $8-\mathrm{C}-\alpha$-D-glucopyranoside yang berhasil diidentifikasi menggunakan analisis LC-MS.

\section{Potensi Lotus corniculatus L. sebagai Antidepresan}

Pada penelitian Dereli et al (2020) ekstrak metanol bagian udara Lotus corniculatus L. (100 $\mathrm{mg} / \mathrm{kgBB}$ ) secara signifikan mengurangi waktu imobilitas pada pengujian forced swim test (FST) dan tail suspension test (TST) yang dibandingkan dengan imipramine $\mathrm{HCl}$ (30 dan 50 $\mathrm{mg} / \mathrm{kgBB})$. Ekstrak metanol bagian udara Lotus corniculatus L. (100 mg/kgBB) juga meningkatkan aktivitas lokomotor, menurunkan skor ptosis dan mengubah suhu rektal pada 
pengujian antagonisme hipotermia dan ptosis yang diinduksi tetrabenazine. Senyawa aktif yang berperan dalam aktivitas antidepresan Lotus corniculatus L. adalah medicarpin-3-Oglucoside, gossypetin-3-O-glucoside dan naringenin-7-O-glucoside yang berhasil diisolasi dari fraksi metanol bagian udara Lotus corniculatus L. Senyawa aktif tersebut bekerja dengan cara menghambat enzim MAO-A dan MAO-B dengan nilai IC50 yang tinggi dalam uji penghambatan MAO.

\section{Potensi Omrisia henry prain sebagai Antidepresan}

Fraksi etanol daun ormosia henryi prain dosis $150 \mathrm{mg} / \mathrm{kg}$ BB secara signifikan meningkatkan indeks preferensi sukrosa pada sucrose preference test (SPT), mengurangi latensi penelanan pada ingestion latency test (ILT) dan secara signifikan memperpanjang aktivitas lokomotor dan mengurangi waktu imobilitas pada tail suspension test (TST), serta ekspresi BDNF pada dosis ini meningkat secara signifikan. Hal ini menunjukkan bahwa fraksi etanol daun Ormosia henryi prain menghasilkan efek seperti antidepresan. Senyawa aktif yang berperan sebagai antidepresan dari daun Ormosia henryi prain adalah luteolin 6-C-glucoside (isoorientin), luteolin 8-C-glucoside (orientin) dan apigenin 6-C-glucoside (isovitexin) (Lu et al., 2019).

\section{Potensi Prosopis cineraria sebagai Antidepresan}

Tumbuhan ini dikenal dengan nama "Kalpataru" karena semua bagian dari tumbuhan ini memiliki manfaat (Burkart, 1976). Pada penelitian George et al (2012) ekstrak air daun Prosopis cineraria menunjukkan aktivitas antidepresan pada dosis $200 \mathrm{mg} / \mathrm{kgBB}$ dengan menurunkan waktu imobilitas secara signifikan pada mencit yang diuji dengan forced swim test (FST). Efek antidepresan ini sebanding dengan obat imipramine (15 mg/kg. p.o).

\section{Kesimpulan}

Berdasarkan penelusuran pustaka yang telah dilakukan, dapat disimpulkan bahwa Albizzia julibrissin, Cassia singueana, Ceratonia siliqua L., Erythrina variegata, Trigonella foenumgraecum, Lotus corniculatus L., Ormosia henryi prain dan Prosopis cineraria memiliki aktivitas antidepresan. Dari beberapa penelitian, tumbuhan Trigonella foenum-graecum, Lotus corniculatus L. dan Ormosia henryi prain diketahui memiliki senyawa aktif kaempferol 3-(pcoumaryl) glukosida, quercetin 4-O- $\beta$-d-glucopyranoside, apigenin 4',7-O-diglucoside, schaftoside, isoschaftoside, apigenin 8 -C- $\alpha-\mathrm{D}$-glucopyranoside, medicarpin-3-Oglucoside, gossypetin-3-O-glucoside,naringenin-7-O-glucoside,luteolin 6-C-glucoside (isoorientin), luteolin 8-C-glucoside (orientin), dan apigenin 6-C-glucoside (isovitexin) yang berperan dalam aktivitas antidepresan. Oleh karena itu, ketiga tumbuhan ini merupakan tumbuhan yang paling berpotensi sebagai antidepresan. Mayoritas mekanisme kerja antidepresan dari tumbuhan-tumbuhan suku Fabaceae adalah melalui penghambatan enzim Monoamine Oxidase (MAO).

\section{Acknowledge}

Peneliti mengucapkan terima kasih kepada Ibu Apt. Sri Peni Fitrianingsih, M.Si selaku pembimbing utama dan Ibu Apt. Ratu Choesrina, M.Si selaku pembimbing serta yang telah meluangkan waktu, tenaga dan pikiran dalam memberikan pengarahan, pengajaran, saran dan bimbingan kepada penulis selama pelaksanaan dan penulisan artikel ini.

\section{Daftar Pustaka}

[1] Adzu, B., Abbah, J., Vongtau, H., \& Gamaniel, K. (2003). 'Studies on the use of Cassia singueana in malaria ethnopharmacy', Journal of Ethnopharmacology, 88(2-3), 261267.

[2] Agrawal, A., Mohan, M., Kasture, S., Foddis, C., Frau, M. A., Loi, M. C., \& Maxia, A. (2011). 'Antidepressant activity of Ceratonia siliqua L. fruit extract, a source of polyphenols', Natural Product Research, 25(4), 450-456.

[3] Alkali YI, Abdulgafar OJ, Yerima M and Abubakar K. (2018). 'Antischizophrenic and central nervous system depressant effects of Cassia singueana', Australian Journal of 
science and technology.

[4] Avallone, R., Plessi, M., Baraldi, M., \& Monzani, A. (1997). 'Determination of chemical composition of carob (Ceratonia siliqua): protein, fat, carbohydrates and tannins', Journal of Food Composition and Analysis, 10, 166-172.

[5] Burkart, A. (1976). 'A monograph of genus Prosopis (Leguminous)',.J. Arnold Arboretum.

[6] Chwil, M., Gawron, R.M., Terlecka, P., Kostryco,M. (2017). 'Plant Antidepressants In Selected Species From The Family Fabaceae - A Review', Annales Horticulturae, VOL. XXVII.

[7] Dereli, F.T.G., Khan, H., Sobarzo-Sánchez, E., \& Akkol, E. K. (2020). 'Antidepressant Potential of Lotus corniculatus L. subsp. corniculatus: An Ethnobotany Based Approach', Molecules, 25(6), 1299.

[8] George, M., Joseph, L., Sharma, A. (2012). 'Antidepressant and skeletal muscle relaxant effects of the aqueous extract of the Prosopis cineraria', Brazilian Journal of Pharmaceutical Sciences, vol. 48.

[9] Hawari, D. (2011). Manajemen Stres, Cemas dan Depresi, Fakultas Kedokteran Universitas Indonesia, Jakarta.

[10] Ibrahim, A.I., Abubakar, K., Musa, Y., Ahmed,A.H., Gada, M.H., Maitambari, F.Y. (2019). 'Anxiolytic and antidepressant potential of methanol leaf extract of Cassia singueana f. (fabaceae)', GSC Biological and Pharmaceutical Sciences, 07(02), 007015.

[11] Jung MJ, Kang SS, Choi JS. (2003). 'A new (E)4-hydroxy-dodec-2-enedioic acid from the stem bark of Albizzia julibrissin', Arch Pharm Res, 26:207-9.

[12] Jung MJ, Kang SS, Jung HA, Kim GJ, Choi JS. (2004). 'Isolation of flavonoids and a cerebroside from the stem bark of Albizzia julibrissin', Arch Pharm Res, 27:593-9.

[13] Kementerian Kesehatan RI. (2019). INFODATIN Situasi Kesehatan Jiwa Di Indonesia,Jakarta.

[14] Kim, J.-H., Kim, S. Y., Lee, S.-Y., \& Jang, C.-G. (2007). 'Antidepressant-like effects of Albizzia julibrissin in mice: Involvement of the 5-HT1A receptor system', Pharmacology Biochemistry and Behavior, 87(1), 41-47.

[15] Kinjo J, Araki K, Fukui K, Higuchi H, Ikeda T, Nohara T, et al. (1992). 'Six new triterpenoidal glycosides including two new sapogenols from Albizziae Cortex', $V$. Chem Pharm Bull, 40:3269-73.

[16] Langran, X., et al. (2010). Flora of China: Fabaceae. Beijing: Science Press.

[17] Lu, Y., Zhu, S., He, Y., Peng, C., Wang, Z., \& Tang, Q. (2019). 'Phytochemical Profile and Antidepressant Effect of Ormosia henryi Prain Leaf Ethanol Extract', International Journal of Molecular Sciences, 20(14), 3396.

[18] Martins, J., \& Brijesh, S. (2019). 'Anti-depressant activity of Erythrina variegata bark extract and regulation of monoamine oxidase activities in mice', Journal of Ethnopharmacology.

[19] Mezrag, A., Mohamed, B., Nicola, M., Massimiliano, D., Aissaoui, M., Lorella S. (2014). 'Phytochemical investigation and citotoxix activity of Lotus corniculatus', Pharmacology Online, 3, 222-225.

[20] Reynaud, J., Jay, M., Raynaud, J. (1982). 'Flavonoid glycosides of Lotus corniculatus (Leguminosae)', Phytochemistry 21, 2604-2605.

[21] Walewska, E., Strzelecka, H. (1984). 'Flavonoid compounds in aerial parts of Lotus corniculatus L.', Herba Polonica 30, 151-157.

[22] Wang, J., Cheng, C., Xin, C., \& Wang, Z. (2019). 'The Antidepressant-like Effect of Flavonoids from Trigonella Foenum-Graecum Seeds in Chronic Restraint Stress Mice via Modulation of Monoamine Regulatory Pathways', Molecules, 24(6), 1105. 